This Journal is available in Telkom University online Journals

Jurnal Manajemen Indonesia

\title{
Strategi Pembangunan Perekonomian Provinsi Lampung
}

\author{
Appin Purisky Redaputri ${ }^{1}$, M Yusuf S Barusman ${ }^{2}$ \\ ${ }^{1}$ Faculty of Economy and Business, Bandar Lampung University, Lampung, Indonesia \\ ${ }^{2}$ Faculty of Economy and Business, Bandar Lampung University, Lampung, Indonesia
}

\begin{abstract}
The purpose of this study is to determine the current condition of the Lampung economy, and determine the economic development strategy that should be done to improve the Lampung Human Development Index (HDI) in the future. This research uses a qualitative method. Data are collect through a study literature and Focus Group Discussion (FGD) with practitioners and Lampung economic observers. The results show that there are three strategies of economic development of Lampung Province, namely agricultural revolution, transformation of market structure and entrepreneurship development that focuses on cultural-based tourism.
\end{abstract}

Keywords-Economic Development Strategy; Agricultural Revolution; Market Structural Transformation; Cultural-Based Tourism.

\begin{abstract}
Abstrak
Tujuan penelitian ini adalah untuk mengetahui kondisi perekonomian Lampung terkini, dan menentukan strategi pembangunan perekonomian yang sebaiknya dilakukan untuk memperbaiki Indeks Pembangunan Manusia (IPM) Lampung kedepannya. Penelitian ini bersifat kualitatif. Data dikumpulkan melalui study literature dan pelaksanaan Focus Group Discussion (FGD) dengan para praktisi dan pengamat perekonomian Lampung. Hasilnya didapatkan yaitu terdapat tiga strategi pembangunan perekonomian Provinsi Lampung yaitu melakukan revolusi pertanian, transformasi struktur pasar dan pengembangan kewirausahaan yang fokus kepada wisata berbasis budaya.
\end{abstract}

Kata Kunci-Strategi Pembangunan Perekonomian; Revolusi Pertanian; Transformasi Struktur Pasar; Wisata Berbasis Budaya.

\section{PENDAhULUAN}

Lampung merupakan salah satu lumbung pangan nasional, karena sebagian besar tanaman pangan, hasil perkebunan dan perikanan ada di Lampung. Adapun beberapa contoh komoditas unggulan yang menjadi produk unggulan Lampung antara lain jagung, coklat, gula, kopi, ubi kayu, udang, dan nanas. Jagung misalnya, Lampung merupakan podusen jagung nomor tujuh di Indonesia. Selanjutnya coklat, produksi coklat Lampung merupakan produksi coklat nomor enam terbesar di Indonesia. Untuk hasil tebu yang diolah menjadi gula, Lampung merupakan produsen gula nomor empat di Indonesia. Selanjutnya adalah kopi Lampung. Lampung merupakan produsen kopi nomor dua di Indonesia. Lampung juga merupakan produsen ubi kayu, udang, dan nanas nomor satu di Indonesia. Untuk penghasil udang, Lampung sebagai penghasil udang terbesar yang berkontribusi sebesar 60 persen nasional (BPS diolah, 2015).

Walaupun Lampung merupakan lumbung pangan nasional, Indeks Pembangunan Manusia (IPM) Lampung merupakan IPM terendah di Sumatera. Angka IPM Lampung Tahun 2017 mencapai 68,25\%. IPM merupakan gabungan dari komponen Perekonomian, Pendidikan, dan Kesehatan.

\section{Article info}

Received (6 $6^{\text {th }}$ July, 2018)

Revised (25 July, 2018)

Accepted (16 ${ }^{\text {th }}$ August, 2018)

Corresponding_author: appin@ubl.ac.id, yusuf.barusman@ubl.ac.id 


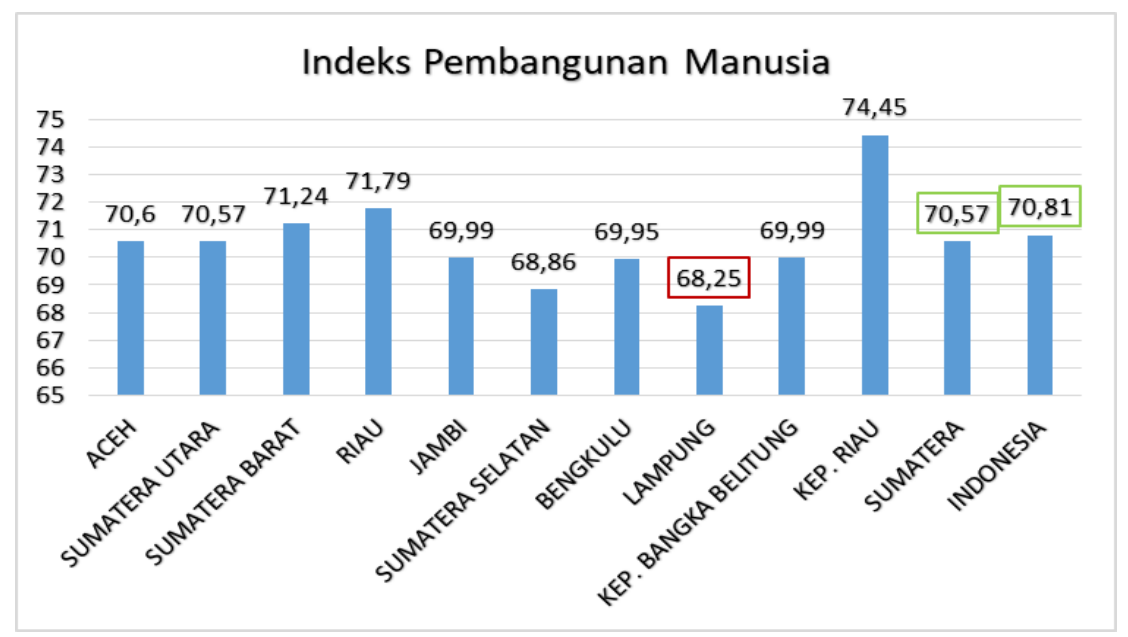

Gambar 1. Indeks Pembangunan Manusia Pulau Sumatera dan Indonesia 2017 (Sumber: BPS Provinsi Lampung-diolah, 2017)

Dari Gambar 1. terlihat bahwa Lampung merupakan Provinsi dengan IPM terendah di Pulau Sumatera pada tahun 2017 dengan angka 68,25\%. Angka tersebut masih berada dibawah rata-rata Pulau Sumatera 70,57 \% dan rata-rata Nasional yaitu 70,81 \% (BPS Provinsi Lampung, 2017).

Selain dari segi IPM, tingkat kemiskinan merupakan salah satu komponen perekonomian yang berhubungan dengan angka harapan hidup. Semakin banyak masyarakat miskin di suatu daerah pasti akan mempengaruhi angka harapan hidup masyarakat di daerah tersebut. Lampung dengan tingkat kemiskinan 13,69\% merupakan sepuluh besar provinsi termiskin di Indonesia. Angka presentase tingkat kemiskinan Lampung berada di atas rata-rata angka nasional yaitu 10,64\% (BPS Provinsi Lampung, 2017).

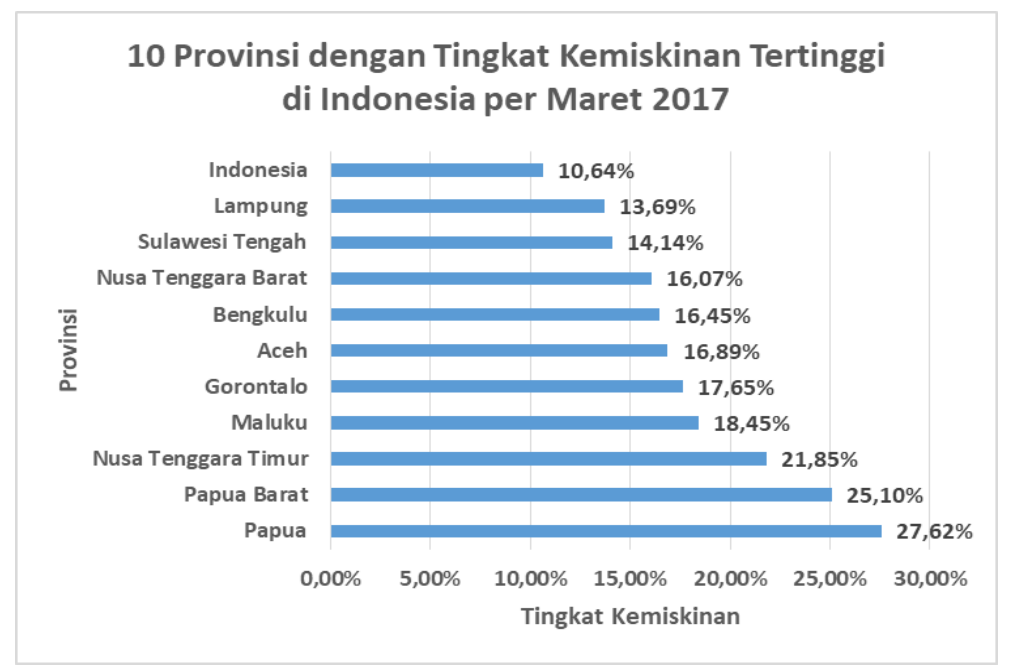

Gambar 2. 10 Provinsi Dengan tingkat kemiskinan tertinggi Maret 2017 (Sumber: BPS- diolah, 2017)

Dari segi pendidikan, pada tahun 2016 angka partisipasi sekolah di Lampung dibawah rata-rata nasional dan rata-rata penduduk Lampung hanya bersekolah selama 7,63 tahun atau sampai dengan SMP. Kemudian angka harapan hidup merupakan indikator untuk mengukur tingkat kesehatan suatu daerah. Angka harapan hidup masyarakat Lampung sampai dengan Tahun 2016 mencapai 69,94 Tahun. Berarti masyarakat Lampung rata-rata hidup hingga umur 69 Tahun. Selain angka harapan hidup, gizi buruk harus menjadi perhatian kita semua. Di Lampung, Prevalensi Balita stunting mencapai 24,8\% dari jumlah penduduknya. Berarti satu dari empat balita di 
Lampung menderita stunting atau kekurangan gizi. Salah satu faktor penyebab kesehatan yang buruk, termasuk gizi buruk, adalah faktor kemiskinan.

Untuk itu penelitian ini bertujuan untuk merumuskan strategi yang bisa dilakukan untuk meningkatkan perekonomian Lampung. Strategi tersebut juga dapat dijadikan rekomendasi program strategi pembangunan perekonomian Provinsi Lampung bagi calon pemimpin Provinsi Lampung periode 2019-2024.

\section{KAJIAN Literatur DAN PENGEMBANGAN HiPOTESIS}

\section{A. Strategi}

Menurut Tjiptono (2006) istilah strategi berasal dari bahasa Yunani yaitu strategia yang artinya seni atau ilmu untuk menjadi seorang jendral. Strategi juga bisa diartikan suatu rencana untuk pembagian dan penggunaan kekuatan militer pada daerah - daerah tertentu untuk mencapai tujuan tertentu. Sedangkan menurut Pearce II \& Robinson (2008), strategi adalah rencana berskala besar, dengan orientasi masa depan, guna berinteraksi dengan kondisi persaingan untuk mencapai tujuan. Rangkuti (2013) berpendapat bahwa strategi adalah perencanaan induk yang komprehensif, yang menjelaskan bagaimana perusahaan akan mencapai semua tujuan yang telah di tetapkan berdasarkan misi yang telah di tetapkan sebelumnya. Menurut David (2011) Strategi adalah sarana bersama dengan tujuan jangka panjang yang hendak dicapai. Strategi bisnis mencakup ekspansi georgafis, diversifikasi, akuisisi, pengembangan produk, penetrasi pasar, pengetatan, divestasi, likuidasi, dan usaha patungan atau joint venture. Strategi adalah aksi potensial yang membutuhkan keputusan manajemen puncak dan sumber daya perusahaan dalam jumlah besar. Jadi strategi adalah sebuah tindakan aksi atau kegiatan yang dilakukan oleh seseorang atau perusahaan untuk mencapai sasaran atau tujuan yang telah di tetapkan. Dari definisi tersebut, dapat disimpulkan bahwa pengertian dari strategi adalah sebuah tindakan atau proses perencanaan untuk mencapai tujuan yang telah ditetapkan, dengan melalukan hal-hal sesuai keputusan bersama.

\section{B. Pembangunan Ekonomi}

Menurut Sukirno (1996) pembangunan ekonomi ialah usaha meningkatkan pendapatan per kapita dengan jalan mengolah kekuatan ekonomi potensial menjadi ekonomi riil melalui penanaman modal, penggunaan teknologi, penambahan pengetahuan, peningkatan ketrampilan, penambahan kemampuan berorganisasi, dan manajemen. Pembangunan ekonomi didefinisikan dalam beberapa pengertian dengan menggunakan bahasa berbeda oleh para ahli, namun maksudnya tetap sama. Menurut Adam Smith pembangunan ekonomi merupakan proses perpaduan antara pertumbuhan penduduk dan kemajuan teknologi (Suryana, 2000). Todaro (dalam Tarmidi, 1992) mengartikan pembangunan sebagai suatu proses multidimensional yang menyangkut perubahanperubahan besar dalam struktur sosial, sikap masyarakat, kelembagaan nasional maupun percepatan pertumbuhan ekonomi, pengurangan ketidakmerataan, dan penghapusan dari kemiskinan mutlak. Pembangunan ekonomi menurut Irawan \& Suparmoko (2002) adalah usaha-usaha untuk meningkatkan taraf hidup suatu bangsa yang seringkali diukur dengan tinggi rendahnya pendapatan riil perkapita. Meier (dalam Adisasmita, 2005) mendefinisikan pembangunan ekonomi sebagai proses kenaikan pendapatan riil per kapita dalam suatu jangka waktu yang panjang. Sehingga dapat disimpulkan bahwa pembangunan ekonomi merupakan suatu usaha yang dilakukan untuk meningkatkan taraf hidup masyarakat suatu daerah dengan mengolah potensi ekonomi yang ada.

\section{MEtODE PENELITIAN}

Penelitian ini menggunakan pendekatan deskriptif kualitatif. Bogdan \& Taylor (dalam Moleong, 2007) mendefinisikan metodologi kualitatif sebagai prosedur penelitian yang menghasilkan data deskripsi berupa katakata tertulis atau lisan dari orang-orang dan perilaku yang diamati. Selain itu penelitian kualitatif adalah penelitian yang bermaksud untuk memahami fenomena tentang apa yang dialami oleh subjek penelitian secara holistik, dan dengan cara deskripsi dalam bentuk kata-kata dan bahasa, pada suatu konteks khusus yang alamiah dan dengan memanfaatkan berbagai metode ilmiah (Moleong, 2007). Sedangkan penelitian deskriptif adalah penelitian yang berusaha untuk menuturkan pemecahan masalah yang ada sekarang berdasarkan data-data. Penelitian deskriptif memandu peneliti untuk mengeksplorasi dan atau memotret situasi sosial yang akan diteliti secara menyuluruh, luas, dan mendalam (Sugiyono, 2014). Maka penelitian deskriptif kualitatif ini bertujuan untuk mendeskripsikan fenomena yang dialami oleh subjek penelitian pada saat ini secara holistik. Di dalamnya terdapat upaya mendeskripsikan, mencatat, analisis, dan menginterpretasikan kondisi yang sekarang ini terjadi 
atau ada. Dengan kata lain penelitian deskriptif kualitatif ini bertujuan untuk memperoleh informasi-informasi mengenai keadaan yang ada.

Dalam penelitian ini data dikumpulkan melalui studi literatur serta pelaksanaan Focus Group Discussion (FGD) dengan para narasumber. FGD atau diskusi kelompok terarah merupakan bentuk kegiatan pengumpulan data melalui wawancara kelompok dan pembahasan dalam kelompok sebagai alat/media paling umum digunakan dalam metode PRA maupun ZOPP (Indrizal, 2014). FGD pada penelitian ini dihadiri oleh 10 orang narasumber, termasuk di dalamnya satu orang moderator. FGD dilakukan pada hari Rabu, tanggal 21 Maret 2018 di ruang rapat Rektorat Universitas Bandar Lampung. Sepuluh orang narasumber utama tersebut merupakan perwakilan dari akademisi, praktisi, dan pengamat perekonomian Lampung. Tabel 1 dibawah menunjukkan informasi dari narasumber pneleitian ini.

Tabel 1. 10 Narasumber Focus Group Discussion (FGD)

\begin{tabular}{|c|c|c|}
\hline No & Nama Narasumber & Pekerjaan \\
\hline 1. & Dr. Ir. H. M. Yusuf. S. Barusman, M.B.A & $\begin{array}{l}\text { Rektor Universitas Bandar Lampung dan } \\
\text { Ketua ICMI Orwil Lampung }\end{array}$ \\
\hline 2. & Dr. Ayi Ahadiyat, S.E., M.B.A & $\begin{array}{l}\text { Dosen FEB UNILA dan Ketua ISEI Cab } \\
\text { Lampung }\end{array}$ \\
\hline 3. & Dr. Marselina Djayasinga, S.E.MPM & $\begin{array}{l}\text { Dosen FEB Universitas Lampung, Wakil } \\
\text { Ketua Dewan Pengupahan Provinsi } \\
\text { Lampung }\end{array}$ \\
\hline 4. & Dr. Agus Nompitu, SE, M.T.P & $\begin{array}{l}\text { Birokrat pada Pemerintah Provinsi } \\
\text { Lampung Bidang Koperasi }\end{array}$ \\
\hline 5. & Ir. Indriati Agustina Gultom, M.M & Dosen FEB Universitas Bandar Lampung \\
\hline 6. & Ardiansyah SH & $\begin{array}{l}\text { Dewan Penasehat ICMI Orwil Lampung } \\
\text { dan GM Radar Lampung }\end{array}$ \\
\hline 7. & Dr. Habiburrahman, S.E.,M.M & Dosen FEB Universitas Bandar Lampung \\
\hline 8. & Ngatiyo & Wakil Ketua ICMI Orwil Lampung \\
\hline 9. & Dr. Iskandar Ali Alam, SE., M.M & Dosen FEB Universitas Bandar Lampung \\
\hline 10. & Drs. Sukismanto Aji M.Si & $\begin{array}{l}\text { Kepala Bidang Ekonomi dan Pembangunan } \\
\text { Balitbangda Provinsi Lampung }\end{array}$ \\
\hline 11. & Asrian Hendi Cahya, SE, M.Si & Dosen FEB UNILA \\
\hline 12. & Ir. Fahrizal Darminto, M.A & Kepala BAPPEDA Provinsi Lampung \\
\hline
\end{tabular}

\section{HASIL DAN PEMBAHASAN}

Dalam merumuskan strategi dan kebijakan yang efektif, terlebih dahulu harus melihat mayoritas kondisi suatu daerah, dengan maksud mempercepat perbaikan atau penyelesaian masalah terbesar. Berdasarkan data dari Badan Pusat Statistik (BPS), diketahui bahwa Product Domestic Regional Bruto (PDRB) menurut Lapangan Usaha Tahun 2016 sebesar 31,45\%, berasal dari kontribusi bidang pertanian, kehutanan, dan perikanan. Selain itu 45,94\% masyarakat Lampung juga berusaha atau bekerja dalam bidang pertanian, perkebunan, perikanan, kehutanan, dan perburuan. Berdasarkan porsi tersebut, usaha untuk memajukan Lampung perlu difokuskan pada bidang Pertanian, Perkebunan, Perikanan, Kehutanan dan Perburuan (BPS Provinsi Lampung, 2016).

Tingkat kemiskinan Lampung yang mencapai 13,69\% (BPS Provinsi Lampung, 2016) berbanding terbalik dengan predikat Lampung sebagai lumbung pangan nasional. Contohnya daerah dengan penduduk miskin terbanyak tahun 2017 yaitu Lampung Timur dengan jumlah penduduk miskin sebanyak 167.640 orang. Kemudian Lampung Tengah sebanyak 162.380 orang, dan Lampung Selatan sebanyak 150.110 orang (BPS Provinsi Lampung, 2016). Pengentasan kemiskinan dilakukan tidak hanya dengan memberikan bantuan instan, namun memberikan wawasan yang berguna sebagai modal masyarakat untuk maju dan mandiri. Untuk itu diperlukan program yang dapat diimplementasikan untuk mengentaskan jumlah orang miskin. 
Dalam mengentaskan kemiskinan, strategi, dan kebijakan yang perlu diprioritaskan adalah revolusi pertanian. Hal pertama yang harus dilakukan adalah peningkatan produktivitas secara revolusioner. Berikutnya adalah revitalisasi dan reformasi lahan pertanian. Saat ini petani di Lampung memiliki lahan dan melakukan cocok tanam namun hasilnya sedikit dan masih banyak digunakan untuk kebutuhan sendiri (subsisten). Selain itu, lahan yang ada sempit sehingga produktivitas para petani juga kecil. Oleh karenanya, perlu dilakukan upaya untuk meningkatkan hasil panen petani yang awalnya hanya 1 ton menjadi 4 ton agar tidak dialih fungsikan. Upaya ketiga dalam menjalankan revolusi pertanian adalah memperbanyak akses teknologi dan modal untuk petani. Semakin canggih alat, semakin banyak informasi, dan semakin meningkatnya modal petani tentu akan mempengaruhi efektifitas kerja petani dan meningkatkan produktivitas mereka. Tidak hanya itu, memaksimalkan pemberdayaan tenaga penyuluh pertanian juga menjadi hal yang penting untuk bisa memberikan wawasan kepada petani secara langsung mengenai proses pertanian yang baru, sehingga proses tersebut bisa menjadi lebih efektif dan efisien. Kemudian pentingnya komitmen dari Pemerintah dalam pelaksanakan riset untuk inovasi pertanian. Tidak hanya mengandalkan Badan Penelitian dan Pengembangan Daerah (Balitbangda) tetapi juga bisa melalui kerjasama dengan perguruan tinggi daerah. Dan yang terakhir adalah pemerintah juga harus memiliki komitmen dalam menentukan proporsi anggaran yang sesuai untuk pertanian. Jika mayoritas masyarakat adalah petani, maka proporsi anggaran dalam APBD harus sesuai.

Penduduk asli Lampung terkenal dengan kegiatan berladang. Mereka berladang tebang bakar dan berpindahpindah. Hasil berladang tersebut digunakan untuk kebutuhan keluarga saja. Penduduk asli Lampung di daerah Way Kanan juga melakukan hal yang sama sejak dulu. Hingga sekarang kampung- kampung tua disana banyak yang sudah ditinggalkan warganya, bahkan bisa dikatakan sepanjang sungai sudah tidak berpenduduk lagi. Untuk itu, perlu dilakukan revolusi pertanian agar lahan kembali hidup dan masyarakat asli memiliki sumber penghasilan kembali.

Strategi dan kebijakan berikutnya dalam upaya mengentaskan kemiskinan adalah transformasi struktur pasar. Pasar monopsoni adalah keadaan di mana satu pelaku usaha menguasai penerimaan pasokan atau menjadi pembeli tunggal atas barang dan/atau jasa dalam suatu pasar komoditas. Kondisi monopsoni sering terjadi di daerah-daerah perkebunan dan industri hewan potong (ayam), sehingga tidak memungkinkan bagi petani untuk melakukan tawar-menawar. Kondisi ini juga terjadi di Lampung. Berbagai hasil pertanian dikuasai oleh satu industri besar. Contohnya adalah produksi ubi kayu. Hasil ubi kayu di Lampung didominasi oleh pabrik tapioka yang merupakan industri besar, sehingga harga jual ubi kayu menjadi rendah. Kondisi ini harus diperbaiki dengan melakukan pemberdayaan kelembagaan ekonomi di tingkat petani. Pemberdayaan kelembagaan ekonomi, terkait dengan pengaturan pasar, penerapan harga jual terendah, bargaining position petani dan pembagian kelompok petani yang kuat dalam kelompok usaha, baik di tingkat desa maupun kabupaten. Kegiatan tersebut didukung dengan adanya koperasi Induk dan Badan Usaha Milik Desa (Bumdes). Contohnya adalah Bumi Dipasena. Desa tersebut merupakan desa penghasil udang terbesar di tingkat nasional. Produknya tidak hanya dijual di dalam negeri tetapi juga di luar negeri. Di Bumi Dipasena, Bumdes berperan penting dan menggunakan prinsip ekonomi kerakyatan yang berbasis syariah. Tidak hanya modal, biaya operasional serta profit, terdapat juga dana untuk risiko usaha bersama, dan sistem bagi hasil.

Upaya kedua dari transformasi struktur pasar adalah pembuatan aturan dalam hal penetapan harga jual terendah untuk beberapa komoditi pokok seperti ubi kayu, sehingga industri besar tidak bisa menekan harga jual hasil pertanian. Upaya selanjutnya adalah dengan melakukan hilirisasi agribisnis berbasis usaha kecil dan menengah (UKM). Selama ini petani menjual hasil panen kepada tengkulak di gudang yang jauh dari lokasi desa. Oleh karenanya pengumpulan hasil panen, penyortiran, pemanasan, dan pengeringan sebaiknya dilakukan di desa, sehingga produk bisa dibawa dari desa dalam bentuk hasil olahan. Untuk mempermudah dan mempercepat penjualan hasil panen, maka diperlukan pembangunan infrastruktur/ pemberdayaan infrastruktur, seperti jalan raya, bandar udara, dan pelabuhan laut sehingga mendekatkan hasil olahan pertanian ke pasar. Pengembangan industri pengolahan juga perlu dikembangkan, agar produk pertanian bisa juga dipasarkan melalui kegiatan E-Commerce. E-Commerce dapat dimulai dari kegiatan penyuluhan dan pelatihan, mengenai cara melakukan E-Commerce oleh beberapa ahli. Hal ini perlu dilakukan agar masyarakat petani mengetahui cara melakukan penjualan elektronik dan mempunyai pasar sendiri.

Dari sisi non-pertanian, upaya yang perlu dilakukan untuk mengentaskan kemiskinan adalah dengan melakukan pengembangan kewirausahaan. Hal ini bisa dilakukan melalui pengembangan wisata alam dan pembangunan pariwisata berbasis budaya dan masyarakat. Wisata berbasis budaya adalah salah satu jenis kegiatan pariwisata yang menggunakan kebudayaan sebagai objek. Menurut Ritchie \& Zins (1978), terdapat 12 unsur kebudayaan yang dapat menarik kedatangan wisatawan yaitu bahasa (language), tradisi masyarakat 
(traditions), kerajinan tangan (handicraft), makanan dan kebiasaan makan (foods and eating habits), musik dan kesenian (art and music), sejarah suatu tempat (history of the region), cara kerja dan teknologi (work and technology), agama (religion) yang dinyatakan dalam cerita atau sesuatu yang dapat disaksikan, bentuk dan karakteristik arsitektur di masing-masing daerah tujuan wisata (architectural characteristic in the area), tata cara berpakaian penduduk setempat (dress and clothes), sistem pendidikan (educational system), dan aktivitas pada waktu senggang (leisure activities). Objek-objek tersebut tidak jarang dikemas dalam bentuk khusus dan lebih menarik bagi turis.

Sebagai contoh, adanya kebijakan-kebijakan untuk mewujudkan Bali yang berbudaya, bertaksu, dinamis, maju, dan modern di bidang pariwisata guna mengembangkan pariwisata kerakyatan yang dapat memberikan efek ganda bagi sebagian besar masyarakat lokal Bali. Contohnya seperti Perda No. 10 Tahun 2013 tentang kepariwisataan budaya Kabupaten Gianyar. Isi kebijakan tersebut yaitu bahwa pariwisata Gianyar berlandaskan kebudayaan Bali umumnya dan Gianyar khususnya yang dijiwai agama Hindu dan falsafah Tri Hita Karana, sehingga terwujud hubungan timbal balik yang dinamis antara kepariwistaan dan kebudayaan yang membuat keduanya berkembang secara sinergis, harmonis, dan berkelanjutan. Contoh lainnya yaitu, untuk mewujudkan visi dan misi Bali Mandara 5 tahun kedepan, terdapat program kerja yang akan dilaksanakan, yakni mengembangkan 100 desa wisata berbasis budaya dan mengembangkan pariwisata spiritual tourism, pertanian atau agriculture tourism, dan olahraga atau sport tourism. Lampung juga bisa mengembangkan pariwisata berbasis budaya dengan memanfaatkan kebudayaan kampung tua dan masyarakat adat. Dengan demikian, akan terbentuk lapangan kerja baru, dan penguatan fleksibilitas ekonomi. Hal ini sejalan dengan Liao (2004) dalam Tjiptono (2015), yakni kewirausahaan akan berkontribusi pada penciptaan lapangan kerja, inovasi produk, mobilitas sosial menuju status yang lebih tinggi, peningkatan kualitas melalui kompetisi, penguatan fleksibitas ekonomi dan peningkatan efisiensi ekonomi.

Hal lain yang bisa dilakukan adalah membuat program pariwisata halal. Melalui program ini Lampung akan menjadi salah satu tujuan wisata halal karena memiliki sertifikasi kuliner halal, sarana ibadah yang baik di tempat wisata dan juga akomodasi halal. Program ini bisa dilakukan melalui kerjasama dengan Majelis Ulama Indonesia (MUI). Usaha selanjutnya adalah mengembangkan industri olahan dari potensi daerah yang ada dan melakukan pemberdayaan industri kreatif berbasis budaya. Contohnya adalah membangun desa wisata tapis berbasis budaya. Karena berbagai macam suku di Indonesia bertempat tinggal di Lampung, maka tidak hanya budaya Lampung, Indonesia mini bisa dihadirkan di Lampung sebagai kampung wisata.

Perlu dicatat bahwa strategi dan kebijakan yang sudah dijabarkan sebelumnya tidak akan berhasil dilaksanakan jika sumber daya manusia (SDM) yang ada tidak memadai. Untuk itu, perlu dilakukan usahausaha peningkatan kualitas SDM yang berfokus pada peningkatan knowledge, skill, dan attitude. Knowledge adalah peningkatan sumber daya manusia yang ada dengan jalan meningkatkan rata-rata lama sekolah masyarakat Lampung. Sedangkan skill adalah meningkatkan kompetensi SDM yang ada dalam industri. Kemudian attitude disa dilakukan melalui gerakan nasional atau daerah untuk menyamakan sikap, menjaga keamanan, kebersihan, jujur untuk mewujudkan kesadaran bersama. Pembinaan Khusus vokasi juga bisa dilakukan untuk mengembangkan kompetensi di luar sekolah.

Memberdayakan masyarakat adat dan kampung tua juga bisa menjadi salah satu upaya pengentasan kemiskinan. Masyarakat adat dan kampung tua juga perlu disentuh dan dibangkitkan lagi keberadaannya. Upaya yang lebih spesifik adalah reformasi yang berfokus pada pembangunan masyarakat adat dan kampung tua. Contoh dari upaya tersebut adalah Pemberdayaan ekonomi masyarakat adat, konservasi budaya kampung tua, pengembangan pariwisata berbasis budaya, dan melakukan pemberdayaan masyarakat adat dalam kelembagaan sosial. Sebagai bentuk realisasi, kegiatan-kegiatan tersebut dapat diaplikasikan di kampung Gedung Meneng Tulang Bawang. Kampung tua di pinggir Way Tulang Bawang ini dipercaya sebagai serpihan Kerajaan Tulang Bawang. Tidak ada lintasan darat lain untuk sampai ke kampung etnik ini, kecuali melewati jalan kebun tebu sejauh 52 kilometer dari Menggala. Perlu usaha ekstra untuk menuju kampung ini. Jalan tanah keras menuju kampung tersebut dikurung debu saat panas dan menjadi becek dan licin saat hujan. Kampung Gedung Meneng ini menyimpan benda-benda peninggalan kuno yang konon memiliki cerita mistis. Di kampung tersebut, rumah-rumah penduduk masih asli, rumat etnis Lampung. Potensi ini perlu dikembangkan menjadi pariwisata berbasis budaya. Dengan melakukan perbaikan pada akses menuju kampung tersebut, pengembangan potensi ini akan menjadi lebih mudah dilakukan. Selain di Tulang Bawang, desa Gedung Batin, Way Kanan juga merupakan kampung tua yang bisa dikembangkan menjadi pariwisata berbasis budaya. Gedung Batin merupakan kawasan pemukiman yang awalnya merupakan contoh pemukiman warga yang dibangun di era 
penjajahan Belanda. Di sana banyak terdapat bangunan tua, bahkan ada yang umurnya lebih dari 400 tahun. Desa ini sudah menjadi master plan pemerintah Kabupaten Way Kanan sebagai desa pariwisata berbasis budaya.

\section{PENUTUP}

\section{A. Kesimpulan}

Berdasarkan hasil penelitian, di peroleh kesimpulan bahwa konflik peran berperan dalam meningkatkan stres Dari pembahasan sebelumnya bisa disimpulkan bahwa dalam melakukan pembangunan perekonomian Lampung terdapat beberapa hal yang perlu dilakukan yaitu melakukan revolusi pertanian melalui peningkatan produktivitas secara revolusioner, revitalisasi dan reformasi lahan pertanian, memperbanyak akses teknologi dan modal untuk petani. Selain itu, memaksimalkan pemberdayaan tenaga penyuluh pertanian juga menjadi hal yang penting guna memberikan wawasan kepada petani secara langsung mengenai proses pertanian yang baru. Untuk mendukung proses pembangunan perekonomian Lampung, komitmen pemerintah dalam hal riset di bidang inovasi pertanian juga diperlukan. Upaya lain adalah transformasi struktur pasar melalui pemberdayaan kelembagaan ekonomi di tingkat petani, pembuatan aturan dalam hal penetapan harga jual terendah untuk beberapa komoditi, melakukan hilirisasi agribisnis berbasis UKM, melakukan Pembangunan dan pemberdayaan infrastruktur, dan pengembangan industri pengolahan guna memasarkan produk pertanian melalui kegiatan Ecommerce. Dari sisi non-pertanian, upaya yang perlu dilakukan adalah melakukan pengembangan kewirausahaan. Upaya ini tidak hanya berfokus pada wisata alam, tetapi juga pariwisata berbasis budaya dan masyarakat, seperti pengembangan masyarakat adat dan kampung tua.

\section{B. Saran}

Strategi pembangunan perekonomian yang dihasilkan dari penelitian ini bisa menjadi masukan untuk pemerintah daerah Lampung selanjutnya. Pelaksanaan strategi pembangunan perekonomian tersebut harus didukung oleh berbagai pihak pengambil keputusan dan menggandeng pihak-pihak pelaku seperti petani, masyarakat terutama masyarakat adat dan kampung tua, lembaga ekonomi dan perguruan tinggi.

\section{DAFTAR PUSTAKA}

Adisasmita, R. (2005). Dasar-dasar Ekonomi Wilayah. Yogyakarta: Penerbit Graha Ilmu.

Badan Pusat Statistik. (2015). Statistik Indonesia. http://bps.go.id. Jakarta. Diakses pada tanggal 2 April 2018.

Badan Pusat Statistik. (2017). Statistik Indeks Pembangunan Manusia (IPM Indonesia). http://lampung.bps.go.id. Lampung. Diakses pada tanggal 2 April 2018.

Badan Pusat Statistik. (2017). Statistik Tingkat Kemiskinan (Tingkat Kemiskinan Indonesia). http://lampung.bps.go.id. Lampung. Diakses pada tanggal 3 April 2018.

Badan Pusat Statistik. (2016). Statistik Produk Domestik Regional Bruto (PDRB). http://lampung.bps.go.id. Lampung. Diakses pada tanggal 4 April 2018.

David, FR. (2011). Manajemen Strategis (Strategic Management). Buku 1. Edisi 12. Jakarta: Salemba Empat.

Indrizal, E. (2014). Diskusi Kelompok Terarah, Focus Group Discussion (FGD), (Prinsip-Prinsip dan Langkah Pelaksanaan Lapangan). Sumatera Barat: Universitas Andalas.

Irawan dan Suparmoko, M. (2002). Ekonomika Pembangunan. Yogyakarta: BPFE.

Liao, J. (2004). Entrepreneurship failures: Key challenges and future directions. Entrepreneurship: the way ahead, 133-150.

Moleong, LJ. (2007). Metodologi Penelitian Kualitatif. Bandung.: PT Remaja Rosdakarya Offset.

Pearce II, J A. dan Robinson JRB. (2008). Manajemen Strategis Formulasi, Implementasi, dan Pengendalian. Jakarta: Salemba empat.

Rangkuti, F. (2013). Teknik Membedah Kasus Bisnis Analisis SWOT Cara Perhitungan Bobot, Rating, dan OCAI. PT. Jakarta: Gramedia Pustaka Utama.

Ritchie, dan Zins. (1978). "Culture as Deterrminant of the Atractiveness of a Tourism Region”, in Ritchie, J.R.B. \& Crouch, G.I. (Eds.). The Competitive Destination: A Sustainable Tourism Perspective. UK: CABI International. pp.115.

Sugiyono. (2014).Metode Penelitian Kuantitaif, Kualitatif dan R\&D, Bandung: Alfabeta.

Sukirno, S. (1996). Pengantar Teori Makroekonomi. Edisi Kedua. Jakarta: PT. Raja Grafindo Persada. 
Suryana. (2000). Ekonomi Pembangunan: Problematika dan Pendekatan. Jakarta: Salemba Empat.

Tjiptono, F. (2006). Manajemen Jasa. Yogyakarta: Andi.

Tjiptono, F. (2015). Kewirausahaan, Kinerja Keuangan dan Kelanggengan Bisnis. Jurnal Manajemen Indonesia, [S.l.], v. 15, n. 1, p. 17-26, apr. 2017. ISSN 2502-3713.

Tarmidi, Lepi, T. (1992). Ekonomi Pembangunan. Jakarta: FEUI. 